OAK RIDGE NATIONAL IABORATORY

Operated by

\title{
Carbide and Carbon Chemicals Company
}

UCC

Post Office Box $P$

Oak Ridge, Tennessee

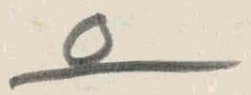

ORNL

Central Files Number

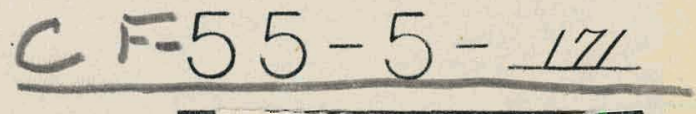

Date:

May 18, 1955

Subject: PRELIMINARY LABORATORY EVALUATION OF AN ELECTRODIALYTIC METHOD FOR THE TREATMENT OF RADIOACTIVE WATERS

\section{LEG $\triangle$ I NOTICL}

This report was prepared as an account of Government sponsored work. Nelther the United States, nor the Commission, nor any person acting on behalf of the Commission:

A. Makes any warranty or representation, expressed or implied, with respect to the accu$y$, completeness, or usefulness of the information contained in this report may not infringe of any information, apparatus, method, or process disclosed in this roport, or the the
privately owned rights; or privately owned right; or

B. Assumes any liabilities with respect to the use of, or for damages rest.

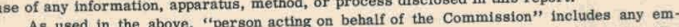
poyee or contractor of the Commission, or employee of such contractor, to the extent that such employee or contractor of the Commission, or enployeo of such contractor prepares, disseminates, or provideo access to, any information pursuant to tis emploger 


\section{DISCLAIMER}

This report was prepared as an account of work sponsored by an agency of the United States Government. Neither the United States Government nor any agency Thereof, nor any of their employees, makes any warranty, express or implied, or assumes any legal liability or responsibility for the accuracy, completeness, or usefulness of any information, apparatus, product, or process disclosed, or represents that its use would not infringe privately owned rights. Reference herein to any specific commercial product, process, or service by trade name, trademark, manufacturer, or otherwise does not necessarily constitute or imply its endorsement, recommendation, or favoring by the United States Government or any agency thereof. The views and opinions of authors expressed herein do not necessarily state or reflect those of the United States Government or any agency thereof. 


\section{DISCLAIMER}

Portions of this document may be illegible in electronic image products. Images are produced from the best available original document. 
Introduction

1/ An electrodialytic method using permselective ion exchange membranes is described which bas been used on a laboratory scale for the decontrmination of radioactive wastes and for the concentration of radioelements contained in low-level radioactive waters at oak Ridge National Laboratory. The application of this method for decontamination purposes is of interest in the treatment of low-level radioactive wastes or in the treatment of drinking water supplies which have been rendered unsafe through radioactive contamination. The use of the method for concentrating contaminants contained in a solution is of particular. importance where radiochemical analyses of low-level wastes are required.

The laboratory studies described are of prellminary nature. In view of the versatility of the method for the concentration of any Ionic constituents in water, these preliminary findings may be of interest in solving other water treatment problems /

The Electrodialytic Cells Utilized

Electrodialysis combines electrolysis with dialytic diffusion in transporting ionic impurities through semf-permeable membranes under the influence of an applied electrlc potential. In the simplest form, an electrodialytic cell consists of three compartments, namely, an anode compartment where anions are concentrated, a cathode compartment where cations are concentrated, and a middle or dialysate compartment through which the water to be delonized is passed. As shown in Figure 1 , these compartments are separated by the semi-permeable membranes. Electrodes of some corrosion resistant conducting material are inserted in the outer cathode and anode compartments and a source of direct current of suitable voltage is applied. 
For economic reasons, full-scale electrodialytic treatment units consist of multi-compartmented cells $(1,2)$. In determining the delonization efficiency of the process, a three-compartment cell is adequate and was preferred in these studies because of the simplicity of fabrication.

One type of cell designed in this laboratory is a liucite or Bakelite tube cut into three compartments (Figure 1). The cell diameter varied from one to four Inches. The anode and cathode (electrode) compartments, one inche long, are separated from the central dialysate compartment, one-half inch long, by appropriate permselective'membranes. Platinum grid electrodes are immersed in the electrode compartments, which are then closed with rubber stoppers clamped in place at either end of the cell. The permselective membranes separating the dialysate compartment from the electrode compartments form effective gaskets for perventing leakage from the cell. Two one-quarter inch holes are drilled diametrically opposite in each of the three compartments. Tygon tubing is inserted into the holes, allowing the passage of anolyte, catholyte, and dialysate through the cell. The assembly is clamped in a horizontal position, and the dialysate compartment filled with glass beads to insure greater hydraulic efflciency and to oupport the membranes. A potential is appiled across the cell from a variable-voltage rectifier operated from a standard 110-volt line. The maximum current was limited to 200 milliamperes (D.C.) and maximum voltage to 200 volts with this supply. A second type of electrodialytic cell was constructed similar to that described in a publication by the Central National Council for 
Applied Sclentific Research, in the Netherlands (2). A sketch of this cell is shown in Flgure 2. The cell can be constructed of Bakelite or any rigid plastic material. The approximate over-all dimensions of this cell are $2 \times 3 \times 1 / 2$ inches, and the effective area of each membrane is about 4 square inches. Thickness of the central compartment is approximately $2 \mathrm{~mm}$. Platinum grids served as electrodes in the outer compartments. This type of cell permits a higher flow rate of dialysate than the tubular cell, without increasing power requirements. Both of the electrode compartments were equipped with inlet and outlet ports for circulation of the anolyte and catholyte solutions.

The current density depends primarily upon the ionic strength of the dialysate and its flow rate. These variables are interdependent, and the establishment of optimum operating criteria depends on the specific experimental conditions. To insure a minimum voltage drop across the electrode compartments, both compartments were initially charged with a dilute solution of a suitable electrolyte, for example, 0.001 normal KCI solution.

The membranes used in this work were Amberplex C-1 (cation permeable) and Amberplex A-I (anion permeable), supplied by the Rohm and Haas Company, Resinous Products Division, Philadelphia, Pennsylvania. Functional characteristics of the membranes may be obtained in the manufacturer's iiterature ${ }^{(3)}$.

To evaluate deionization efficiency in each experiment, measurements were made of the removal of radioactive materials, the removal of hardness, and in some instances, specific conductivity measurements were

\section{4}


also obtained. Other parameters recorded during each study included flow rate, applied voltage, and resulting current. The type and concentration of electrolyte inftially added to the electrode compartments was also varied and, in some cases, the anolyte and catholyte solutions were recirculated. For most studies, a single electrodialytic cell was used; however, two or three cells were sometimes used in series, with each cell operated from a separate power supply.

\section{Laboratory Investigations.}

The Decontamination of Radioactive Waters

Waters, containing various radiocontaminants, were passed through the dialysate compartment of tubular-type cells, one inch in diameter. Detalls of operation and removal efficiencies obtained are summarized in Table $I$.

Radiocollotdal materials in the influent are only partially removed as is shown in runs 9 and 10 using $\mathrm{Zr}^{95}-\mathrm{Nb}^{95}$. However, such colloids can be removed by pre- or post-treatment with coagulation-type processes. In studies using solutions containing mixed fission products (Runs 11, 13, and 14), a large percentage of the radioactivity remaining following electrodialytic treatment is present in colloidal form. This was demonstrated by passing the effluent solutions through sand filter. beds or by coagulating with iron salts, whereby a substantial portion of the remaining radioactive material was removed.

Continued operation of a cell with tap water as influent caused a gradual build-up of sparingly soluble calcium and magnesium salts in the catholyte compartment. Precipitation of these salts led to clogging 
of the drainage tubes and decreased efficiency of the cation permeable membrane. This situation became especially marked in certain qualitative experiments designed to examine remoral efficiencies when the electrode solutions were not reclrculated. This effect could be reduced by having the catholyte recirculated and acidified with one molar hydrochloric acid. Relatively concentrated acid ws used to avold possible errors arising. from the effect of dilution. In general, the ratio of flow rate of dialysate to that of the combined anolyte and catholyte could be maintained in the order of 100 to 1 without appreciable clogging or loss of demineraization efficicney.

To permit higher flow rates, several of these experiments were repeated, using substantially larger cells, the largest being four inches in diameter. In this manner, flow rates up to $75 \mathrm{ml} / \mathrm{min}$ could be obtalned while malntaining removals of activity and total hardness of over 95 per cent from tap water solutions. Results of studies to determine the removal of $\mathrm{Sr}^{89}$ from various solutions using four-inch diameter cells are summarized in Table II. The effects of added carrier (1onic concentration), flow rate, and number of celis in series are manifest in these results. It should be emphasized that demineralization efficiency is primarily dependent on eeli desiga. Thus, the results obtained are not Indicative of the optimum efficiencles which may be attained by the electrodialytic method, but show the comparative effects of the parameters involved as a function of the cell design employed.

To improve the cell design, the plate-type cell depicted in Figure 2 was constructed. In addition, provision was made for recirculation 
and processing of the anolyte and catholyte solutions to minimize the effects of precipitate formation in the electrode compartments. These solutions were recirculated from separate reservolrs by means of a sigma-motor positive displacement pump. The reservoir beakers comtaining $50 \mathrm{mI}$ of the electrode solutions were continuously stirred with magnetic stirrers, and the $\mathrm{pH}$ of the two solutions was checked at frequent intervals. The $\mathrm{pH}$ of each solution was maintained at or near neutrality by adding increments of $1.0 \mathrm{~N} \mathrm{HCl}$ and $1.0 \mathrm{~N} \mathrm{NaOH}$ to the catholyte and anolyte reservoirs, respectively.

Figure 3 Indicates the results of an experiment designed to evaluate removal efficiency of a typical ionic radioactive contaminant ( $\mathrm{sr}{ }^{89}$ ) and its concentration into $\bar{a}$ minimal. volume of electrode solution. A constant $50-\mathrm{ml}$ volume of anolyte and catbolyte was maintained until the hardness and activity removals fell to 60 per cent. At this point, both anolyte and catholyte were replaced with fresh tap water whereupon removals again returned to the $95+$ per cent range.

Figure 4 shows the results of a similar experiment except that the combined anolyte-catholyte concentrate was recirculated from a common reservoir. No radioactivity was added, the reduction in hardness being the criterion for determining cell efficiency. The results obtained are divided into four separate curves, the first of which indicates the hardness remaining in the effluent when the cell was operated with fresh membranes. For each of the curves, hardness removals decreased as the lonic concentration in the electrode compartments increased. When removal decreased significantly, the compartments were flushed out and a fresh 50-ml 
portion of tap water was added. In each case, replenishment of the electrode solution served to restore the removal efficiency to the $90+$ per cent level. On a rolume throughput basis, however, the over-all operating efficiency is decreasing as may be observed in comparing the four curves . This condition resulted from the build-up of calcium and magnesium deposits on the membranes, as the flushing and changing of electrode solution failed to remove all of the precipitate. The greatest amount of deposition was observed on the concentrate side of the anion permeable membrane. Referring to Figures 3 and 4, the demineralization efficiency. ramaine fairly constant" with fluw-through until a "critical" concentration is reached in the electrode compartments. At this point, the efficiency decreases in a manner analogous to the break-through in an ion exchange resin colum. In the deionization of oak Ridge tap water, this critical concentration occurs at a volume concentration ratio, i.e., volume of dialysate divided by volume of electrode concentrates, of about 80 to 1 , or when the salt concentration in the electrode compartments increases to approximately $0.1 \mathrm{~N}$. Comparison of the results obtained using the two methods of anolyte and catholyte recirculation indicates that the two solutions should not be intermixed in the recirculation cycle. Also, acidification of the catholyte reduces or prevents the formation of precipitates in the cathode compartment.

\section{The Concentration of Low-Level Radioactive Wastes}

Radiochemical analyses of low-level radioactive wastes are of importance in determining the possibility of a health hazard resulting. from the subsequent discharge of such wastes into a watercourse. To 
8

$-8-$

然

facilitate the radiochemical analyses of these dilute wastes, usually large-volume samples must be concentrated in the order of a hundred-fold. The evaporation method is commonly used for this purpose although this method is time consuming and may give erroneous results if volatile radioelements or excessive quantities of inert salts are present. As a consequence, a comparative study was made utilizing the electrodialysis and evaporation methods for concentrating samples of low-level wastes. Four-liter samples of wastes from the Oak Ridge National Laboratory waste disposal system were concentrated by the electrodialytic method using one-inch tubular-type cells. The initial hardness of these wastes was approximately $135 \mathrm{ppm}$ as $\mathrm{CaCO}_{3}$, and the radioactivity levels were in the order of 20 counts per minute per milliliter or $10^{-4}$ microcurie per. milliliter if 10 per cent counting geometry is assumed. A comparison of the radiochemical analysis data obtained by the evaporation and the electrodialysis techniques for one of the samples collected is given in Table III. From these results, it will be noted that the electrodialysis method makes possible the identification of the chemical form of any particular radioelement. With this particular sample, ruthenium, zirconium, and niobium are deposited principally on the membranes in the dialysate compartment, indicating they are colloidal or adsorbed on particulate matter. Strontium, on the other hand, is present principally as a cation. Such information is of importance in predicting the eventual fate of these radioelements in a watercourse.

The discrepancy in the total amounts of radioelements recovered by the two methods may be due to several factors. A prime factor is that intint 
radiochemical analyses of dilute mixtures of radioelements are subject to considerable error. The relative error for those radioelements present In low amounts, such as zirconium, lodine, and niobium in the White Oaks Lake sample, is much greater than for those radioelements present in preponderant quantities such as cesium.

A factor which tends to reduce recovery by the electrodialys is method for certain radioelements is that colloldal particlès may pass through the dialysate compartment. An attempt was made to remove colloldal particles by filtration of solutions containing specific radiolsotopes liruugh millipore tilters. In corollary studies these same solutions were passed through a tubular-type electrodialysis cell. As shown by the results of these studies. (see Table IV), certain radiocollolds, e.g., $\mathrm{Zr}^{95}-\mathrm{mb}^{65}$, can be removed practically completely by filtration whereas those radioisotopes in true solution, e.g., $\mathrm{Co}^{60}$, can be removed by electrodialysis. Certain other radioisotopes, such as $\mathrm{Ru}^{103}$ and $\mathrm{Ce}^{144}-\mathrm{Pr}^{144}$, are only partlally removed by either process.

A further factor tending to reduce recovery by the electrodialysis process is that some radioactive material remains on the. Ion exchange membrane. Attempts were made to regenerate membranes previously used in waste concentration studies by passing distilled water and varlous strength solutions of $\mathrm{K} \mathrm{Cl}, \mathrm{Ba} \mathrm{Cl}$; and $\mathrm{KI}$ through the dialysate compartment. Optimum regeneration was obtained using $0.01 \mathrm{~N} \mathrm{~K} \mathrm{Cl}$ and a potential of 200 volts. With these conditions, maximum removal of radiocontaminants from the membranes was in the order of 50 per cent. 


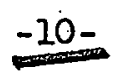

Conclusions

Specific conclusions regarding the preliminary studies reported herein are as follows:

1. To allow continuous operation of an electrodialysis cell, provision should be made for recycling the anolyte and catholyte separately with allowance for treatment and/or bleed-off and replenishment of these solutions. The concentrations in these solutions should be maintained at some maximum value dependent on the required removal efficiency. A value in the order of 0.1 norme]. was obtained for deionlzation efticiencles of 95 per cent with Oak Ridge tap water.

2. The use of the electrodialysis method for concentration of extremely dilute ionic constituents appears feasible. Contaminants present in micro amounts are concentrated percentage-wise essentially to the same degree as contaminants present in macro amounts. Concentration factors in the order of 100 to 1 may be expected for normal surface waters.

3. Electrodialysis may serve as a research tool in determining the physiochemical properties of various water contaminants presen't in a natural stream environment.

\section{Acknowledgment}

The work reported in this document was performed at the Oak Ridge National Laboratory as a part of the cooperative research program of the Oak Ridge National Laboratory and the U.S. Public Health Service. 
1. "Amberplex Ion Permeable Membranes," hohm and Haas Company, Philadelphia, Pennsylvania.

2. Report T.A., 270 of the General Technical Department T.N.0. of $\because$ the Central National Council and Applied Scientific Research in the Netherlands, The Hague.

3. Amberplex A-I (Preliminary Notes): Amberplex C-I (Preliminary Notes), Rohm and Haas Company, Philadelphia, Pennsylvania 


\section{3 \\ TABLE II}

DECONTAMTIATION OF SOLUTIONS CONTAINITG Sr ${ }^{89}$ US ING FOUR-MTGH DIANETER CELIS

\begin{tabular}{|c|c|c|c|c|c|c|c|c|c|c|}
\hline $\begin{array}{l}\text { Run } \\
\text { No. }\end{array}$ & $\begin{array}{l}\text { Influent } \\
\text { Isotope }\end{array}$ & Diluent & $\begin{array}{l}\text { Activity } \\
(\mu \mathrm{c} / \mathrm{ml})\end{array}$ & $\begin{array}{c}\text { Flow } \\
(\mathrm{ml} / \mathrm{mIn})\end{array}$ & $\begin{array}{l}\text { Potentlal* } \\
\text { (volts) }\end{array}$ & $\begin{array}{l}\text { Current Density* } \\
\text { (milliamperes) } \\
\text { (per sq. cm.) }\end{array}$ & $\begin{array}{c}\text { Electro- } \\
\text { lyte }\end{array}$ & $\begin{array}{l}\text { No. } \\
\text { Celis }\end{array}$ & $\begin{array}{l}\text { Activity } \\
\text { Removal } \\
\text { Average }(\%) \\
\end{array}$ & $\begin{array}{l}\text { Hardness } \\
\text { Removal } \\
\text { Average (\%) }\end{array}$ \\
\hline 1 & $\mathrm{sr}^{89}$ & T.W. & $1 \times 10^{-1}$ & 75 & 200 & 1.3 & $10^{-4} \mathrm{NV} \mathrm{KCl}$ & 2 & 95.6 & 96 \\
\hline 2 & $"$ & T.W. & $"$ & 58 & $"$ & 1.0 & $"$ & $"$ & 98.2 & 99 \\
\hline 3 & I & $\begin{array}{l}\text { D.W.+250:ppm } \\
\mathrm{SrCl}_{2}\end{array}$ & " & 20 & 150 & 2.4 & " & $"$ & 99.7 & 99.1 \\
\hline 4 & $"$ & $\because$ & $"$ & 33 & 60 & $"$ & $"$ & $"$ & 88 & 90 \\
\hline 5 & $"$ & $"$ & $"$ & 62 & 60 & $"$ & $"$. & $"$ & 71 & 74 \\
\hline 6 & - " & $\begin{array}{l}\text { D.W.+500 ppm } \\
\mathrm{SrCl}_{2}\end{array}$ & " & 6 & 70 & $"$ & $"$ & $"$ & 99.1 & 98 \\
\hline 7 & $"$ & - " & $"$ & i7 & 40 & $"$ & $"$ & $"$ & 89.2 & 90 \\
\hline 8 & " & $"$ & $"$ & 20 & 50 & $"$ & $"$ & 3 & 99.0 & 98.8 \\
\hline
\end{tabular}

* Where two or more cells are used, values pertain to the last cell in series.

T. W. - Oak Ridge tap water.

D. W. - Distilled water. 


\section{.4 \\ TABLE III}

COMPARISON OF EVAPORATION AND ELECIRODIALYSIS METHODS

FOR CONCEIVIRATION OF WHITE OAK ILAKE EFFLUENT SAMPIE

\begin{tabular}{|c|c|c|c|c|c|c|}
\hline $\begin{array}{l}\text { Radio- } \\
\text { element }\end{array}$ & $\begin{array}{l}\text { Eveporation } \\
\text { Method } \\
\text { (Total c/m) }\end{array}$ & $\begin{array}{c}\text { Catholyte } \\
\text { (Total c/m) }\end{array}$ & $\begin{array}{l}\text { Electrodi } \\
\text { Anolyte } \\
\text { (Total c/m) }\end{array}$ & $\begin{array}{l}\text { 1ysis Method } \\
\text { Dialysate } \\
\text { Deposit } \\
\text { (Total c/m) } \\
\end{array}$ & $\begin{array}{c}\text { Total } \\
\text { Recovered } \\
(\mathrm{c} / \mathrm{m}) \\
\end{array}$ & $\begin{array}{c}\text { Ratio of Total c/m } \\
(\text { Evaporation Method }) \\
\text { (Electrodialytic Method })\end{array}$ \\
\hline $\mathrm{Ru}$ & 2,470 & 160 & 0 & 1,280 & 1,440 & 1.71 \\
\hline $\mathrm{Zx}$ & 760 & * & * & 600 & 600 & 1.27 \\
\hline $\mathrm{drb}$ & 950 & 40 & 90 & 740. & 870 & 1.09 \\
\hline $\operatorname{TRE}$ & 9,700 & 4,200 & 140 & 1,140 & 5,480 & 1.77 \\
\hline Cs & 15,950 & 10,400 & 4,030 & 1,560 & ... 15,990 . & 1.00 \\
\hline $\mathrm{Sr}$ & 9,010 & 5,650 & 0 & 840 & 6,490 & 1.39 \\
\hline$I$ & 850 & 50 & 140 & 80 & 270 & 3.15 \\
\hline TOTALS & 35,200 & 20,500 & 4,250 & 6,520 & 31,270 & 1.12 \\
\hline
\end{tabular}

* Wot determined

c/m - counts per minute

TRE - tri-valent rare earths 


\section{5 \\ TABLE IV}

RENOVAL OF SPECIFIC RADIOISOTOPES FROM SOLUTTON BY

ELECTRODIALYSIS AIVD BY FILIRATION THROUGH MIILIPORE FILTERS

\begin{tabular}{|c|c|c|c|c|c|}
\hline Radioisotope & DiIuent & Elec & trodialysis & Removal Results & Filtration \\
\hline $\mathrm{Zx}^{95} \mathrm{Nb}^{95}$ & B.W. & 30 to $50 \%$ & in dialysate & compartment & $99+\not p$ \\
\hline$" \quad \therefore "$ & $\mathrm{D}_{0} \mathrm{~W}_{0}+2 \mathrm{ppm} \mathrm{Zx}$ and $2 \mathrm{ppm} \mathrm{Nb}$ & $1 n$ & $"$ & $"$ & $"$ \\
\hline " & $\begin{array}{l}\text { D.W. + rasying concentrations } \\
\text { of oxalic acid and versene }\end{array}$ & $"$ & $"$ & $"$ & $"$ \\
\hline$" \quad "$ & D. W. adjusted to $\mathrm{pH} 3,7,11$ & $"$ & $"$ & $"$ & $" \quad "$ \\
\hline $\mathrm{Ru}^{103}$ & D。W。 & 50 to $70 \%$ & in dialysate & compartment & 60 to $70 \%$ \\
\hline$"$. & D. W: $+2 \mathrm{ppm}^{\prime} \mathrm{Ru}^{+6}$ & $"$ & $n$ & $"$ & $" \quad "$ \\
\hline$"$ & D. $\mathrm{W}_{0}+2 \mathrm{ppm} \mathrm{Ru}{ }^{+3}$ & $"$ & $"$ & $"$ & $n$ \\
\hline $\begin{array}{l}\mathrm{Ce}^{144}-\mathrm{Pr}^{144} \\
\mathrm{Co}^{60}\end{array}$ & $\begin{array}{l}\text { D.W. } \\
{ }_{i} D \cdot W .\end{array}$ & $\begin{array}{l}70 \% \text { in cat } \\
99+\% \text { in }\end{array}$ & $\begin{array}{l}\text { holyse compart } \\
\text { catholyte com }\end{array}$ & $\begin{array}{l}\text { tment } \\
\text { partment }\end{array}$ & $\begin{array}{l}60 \text { to } 70 \% \\
0 \%\end{array}$ \\
\hline
\end{tabular}

D.W. - Distilled Water 


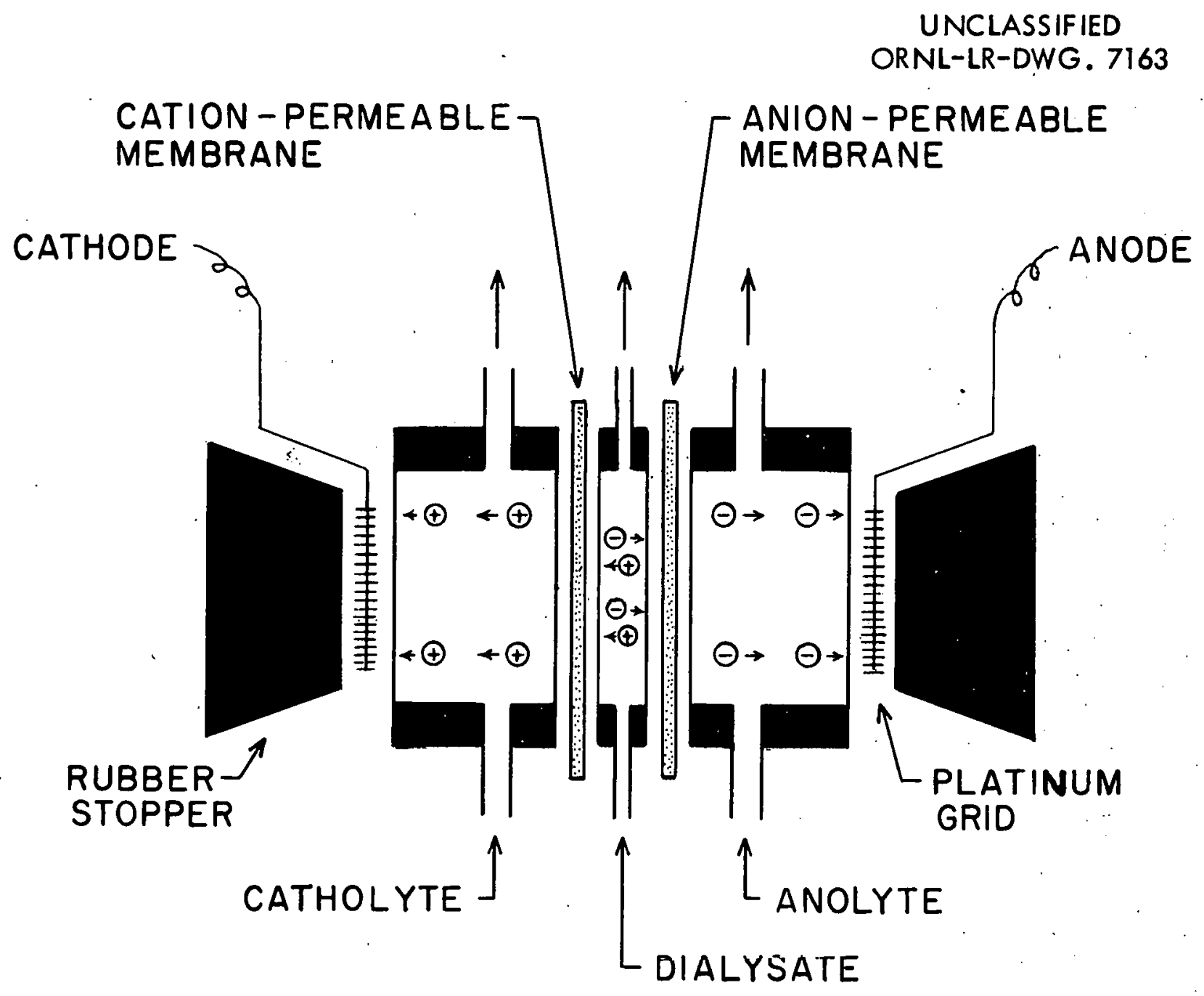

Figure 1

TUBULAR-TYPE ELECTRODIALYSIS CELL CROSS-SECTIONAL VIEW 
UNCLASSIFIED

ORNL-LR-DWG. 7164

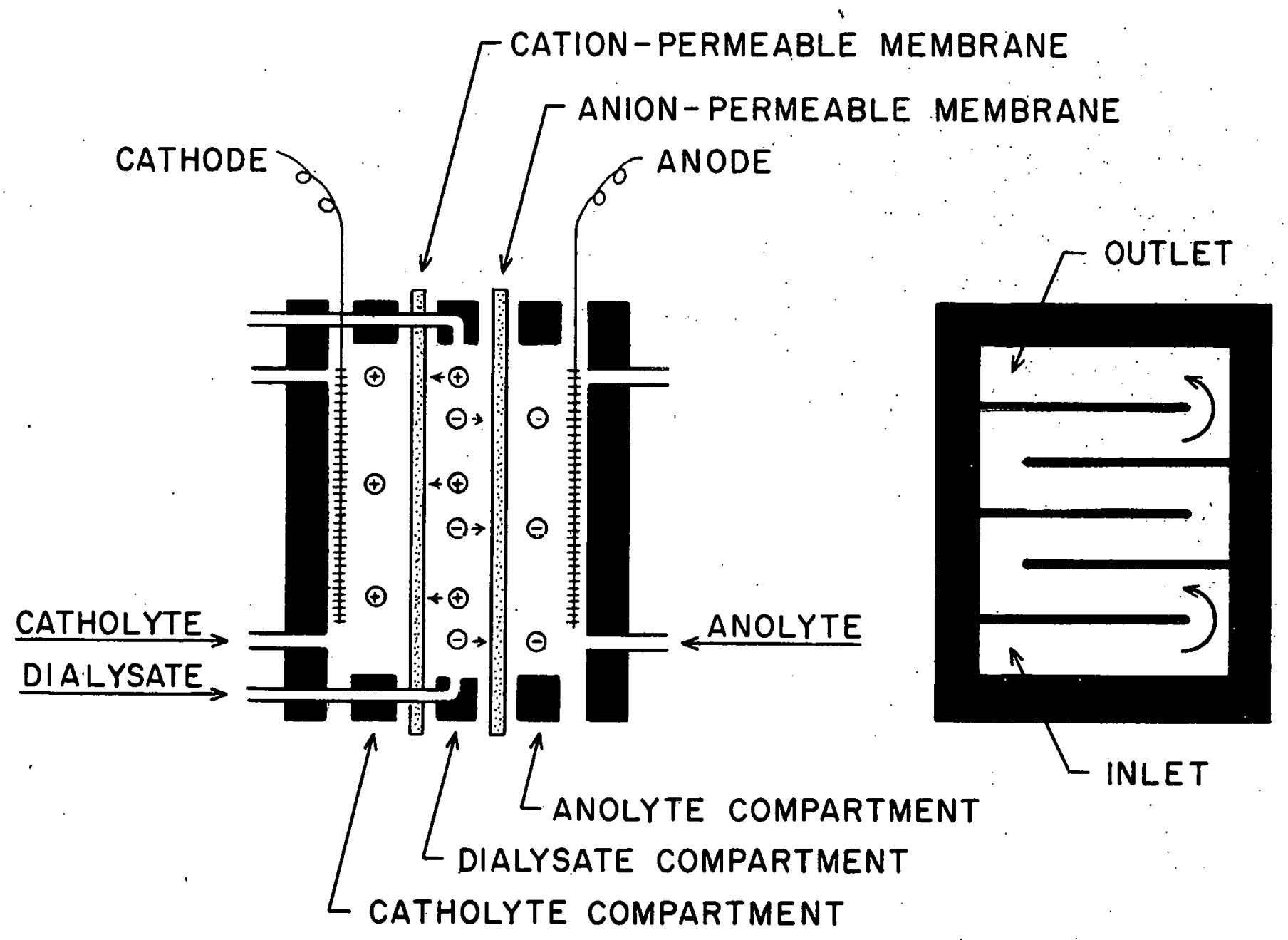

CROSS SECTIONAL VIEW

END VIEW OF

EACH COMPARTMENT

Figure 2

A PLATE - TYPE ELECTRODIALYSIS CELL 


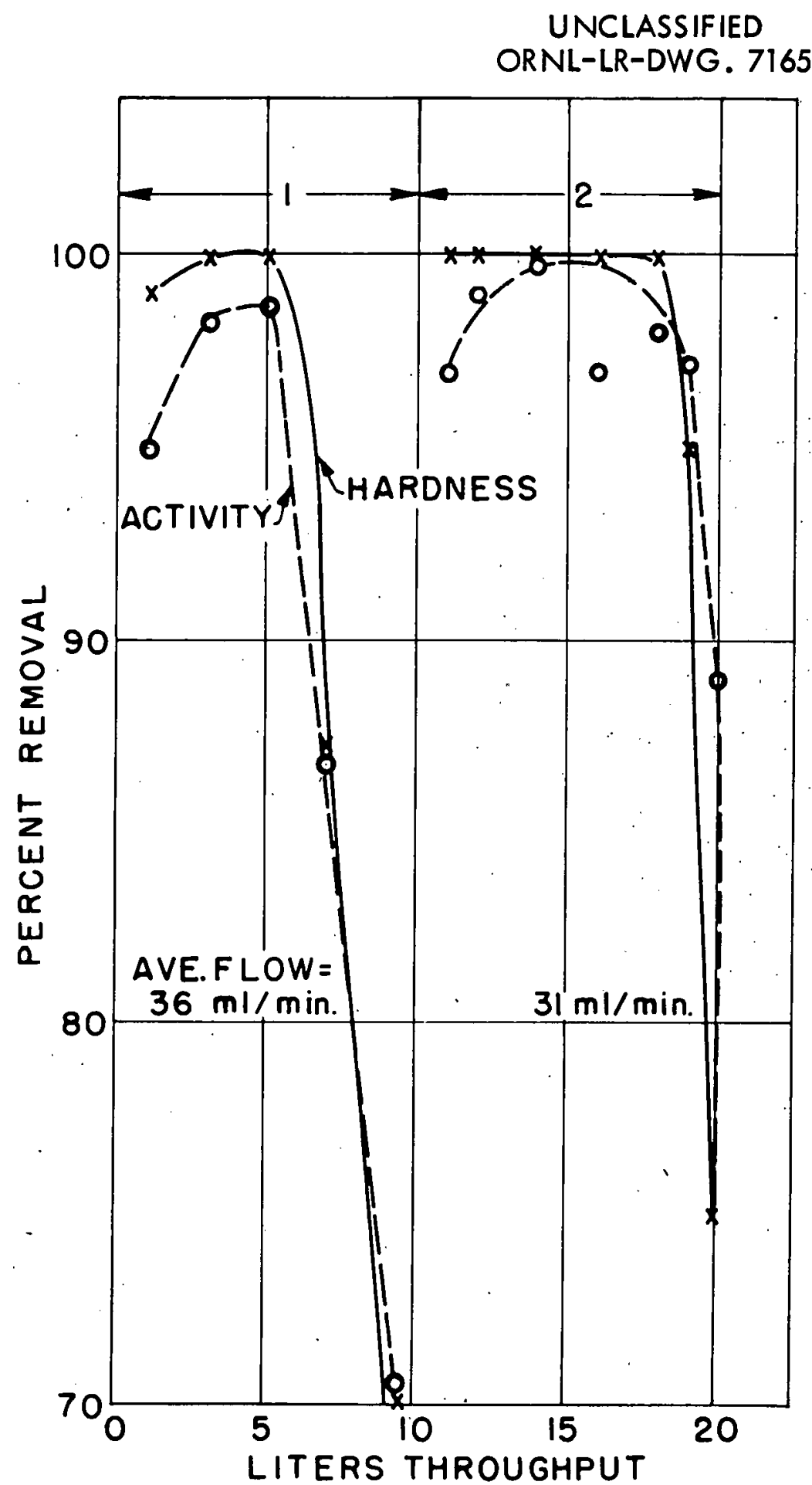

Figure 3

RESULTS USING PLATE-TYPE CELL WITH ANOLYTE AND CATHOLYTE RECIRCULATED SEPARATELY, INFLUENT SOLUTION IS TAP WATER CONTAINING $10^{-2} \mu \mathrm{c} / \mathrm{cc} \mathrm{Sr}^{89}$ 


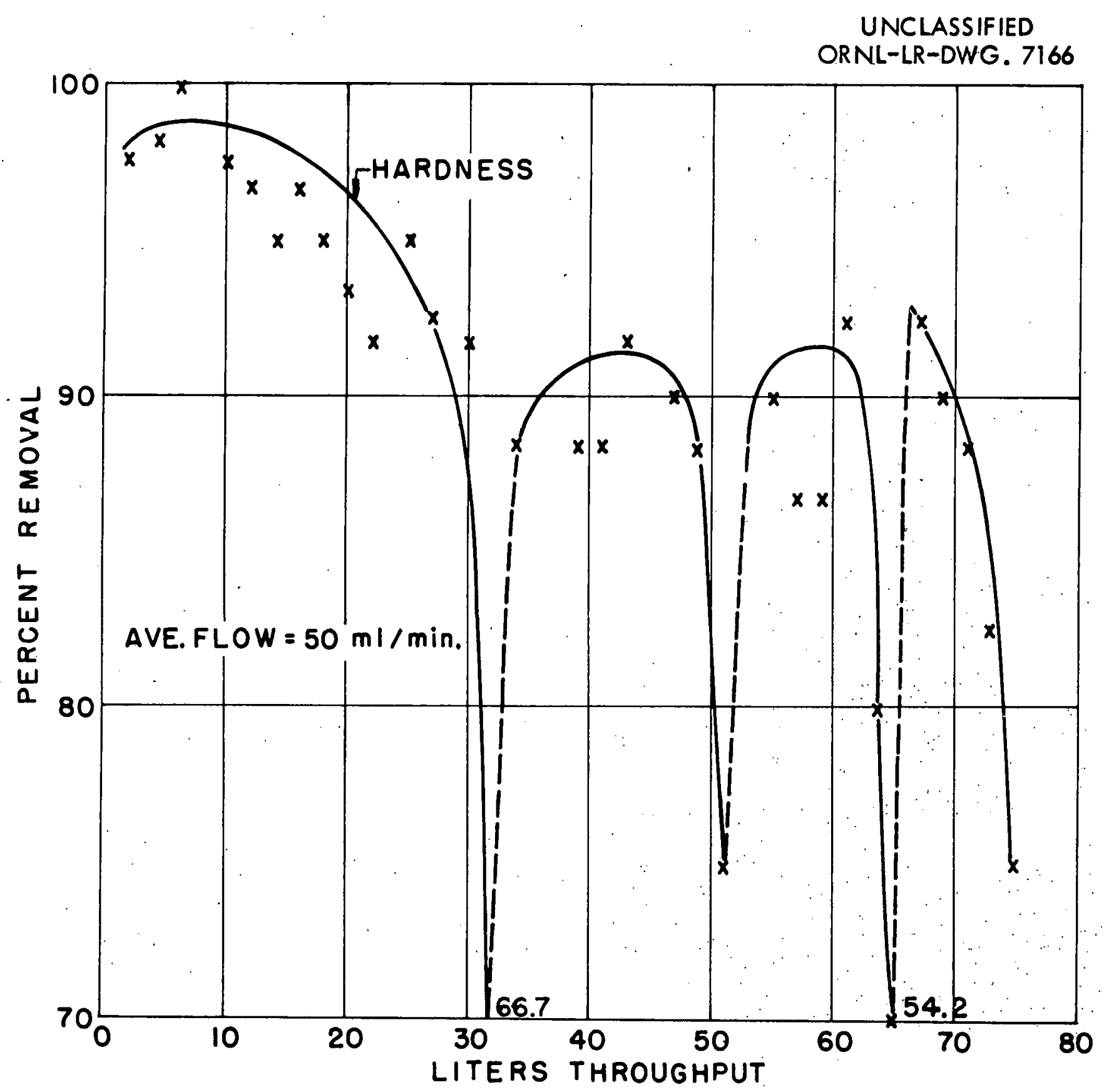

Figure 4

RESULTS USING PLATE-TYPE CELL WITH COMBINED ANOLYTE-CATHOLYTE RECIRCULATED INFLUENT SOLUTION IS TAP WATER 
$0-19$

THIS PAGE

WAS INTENTIONALLY

LEFT BLANK

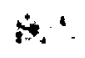

